\title{
External Ear Cartilage
}

National Cancer Institute

\section{Source}

National Cancer Institute. External Ear Cartilage. NCI Thesaurus. Code C49225.

The cartilage in the outer part of the ear. 